\title{
Non-Governmental Organization and Public Crisis Management
}

\author{
Yang Yuanni \\ School of Public Administration, Yunnan University of Finance and Economics, P.R.China, \\ 650021 \\ (E-mail: 30893397@qq.com)
}

\begin{abstract}
Due to the advantages of organizational mechanism and profession knowledge, NGOs have increasingly become an important force to deal with public crisis management and played essential role in modern society. Thus governments should create a benignant environment for the development of NGOs and expand their scope of development. At the same time, NGOs should also improve themselves so as to full play their important role in the public crisis management. According to the characteristics of NGOs, the paper analyses the definition and characteristics of NGOs, examines the essential role of NGOs in the public crisis management and puts forward the specific measures from the bodies of management, social dimensions and institutional construction.
\end{abstract}

Keywords: NGOs, Public Crisis Management, Characteristics, Measures

\section{Introduction}

Public crisis refers to the sudden significant accidents which are related to the public benefits and have important influence on the existence and development of organizations and country. The public crisis is social harmful, latent, and unpredictable, so human beings have to response to this challenge continually. According to the traditional views, the body of public crisis management should be the government instead of other organizations, so the governments should intervene into the public crisis incidents and are responsible fore the settlement. However, the intervention of governments into the public crisis will be failure sometimes due to kinds of different situations. Moreover, the publics of public crisis make the participation and cooperation of enterprises, NGOs and citizens indispensable. The characteristics of NGOs also require that the NGOs should play a positive role in the public crisis management. So the notion of limited government should be established and the scope of governmental responsibilities should be defined, thus the governments can positively cooperate with NGOs in the public crisis management, gradually builds up the notion of mutual cooperation and sharing investment between governments and NGOs and constructs the new mechanism of cooperation, decentralization and decentralization [1]. 


\section{The Connotation of NGO}

International non-governmental organizations have a history dating back to at least the mid-nineteenth century. They were important in the anti-slavery movement and the movement for women's suffrage, and reached a peak at the time of the World Disarmament Conference[2]. However, the phrase "non-governmental organization" only came into popular use with the establishment of the United Nations Organization in 1945 with provisions in Article 71 of Chapter 10 of the United Nations Charter for a consultative role for organizations which are neither governments nor member states - see Consultative Status. The definition of "international NGO" (INGO) is first given in resolution 288 (X) of ECOSOC on February 27, 1950: it is defined as "any international organization that is not founded by an international treaty". The vital role of NGOs and other "major groups" in sustainable development was recognized in Chapter 27 of Agenda 21, leading to intense arrangements for a consultative relationship between the United Nations and non-governmental organizations [3].

Globalization during the 20th century gave rise to the importance of NGOs. Many problems could not be solved within a nation. International treaties and international organizations such as the World Trade Organization were perceived as being too centered on the interests of capitalist enterprises. In an attempt to counterbalance this trend, NGOs have developed to emphasize humanitarian issues, developmental aid and sustainable development. A prominent example of this is the World Social Forum which is a rival convention to the World
Economic Forum held annually in January in Davos, Switzerland. The fifth World Social Forum in Porto Alegre, Brazil, in January 2005 was attended by representatives from more than 1,000 NGOs [4].

The NGO-sector has often been described as extremely diverse, heterogeneous and populated by organizations with hugely varied goals, structure and motivations. It is therefore not an easy task to find a common definition of the term "non-governmental organization". It cannot be based on a legal definition given the wide variations in laws relating to NGO activities, according to which an NGO may have, for instance, the legal status of a charity, non-profit association or a foundation [5].

The term "NGO" can nevertheless be used as shorthand to refer to a range of organizations that normally share the following characteristics: (1) NGOs are not created to generate personal profit. Although they may have paid employees and engage in revenue-generating activities they do not distribute profits or surpluses to members or management; (2) NGOs are voluntary. This means that they are formed voluntarily and that there is usually an element of voluntary participation in the organization; NGOs are distinguished from informal or ad hoc groups by having some degree of formal or institutional existence. (3) NGOs have formal statutes or other governing document setting out their mission, objectives and scope. They are accountable to their members and donors; (4)NGOs are independent, in particular of government and other public authorities and of political parties or commercial organizations [6].

Though these common characteristics can help describe the notion of the term "NGO", it must be borne in mind that their size as well as 
their scope of activities can vary considerably. Some NGOs consist of a rather limited number of persons; others may have thousands of members and hundreds of professional staff. In functional terms NGOs can focus on operational and/or advocacy activities. Operational NGOs contribute to the delivery of services (such as in the field of welfare), whereas the primary aim of advocacy NGOs is to influence the policies of public authorities and public opinion in general. In a broader sense, trade unions and business or professional organizations might also be considered to be non-governmental organizations. The present document, however, deals primarily with organizations active in the so-called "Third Sector", i.e. in the nongovernmental and non-economic field. Nevertheless it goes without saying that the approach to consultation processes proposed in this document should be used as a model for other categories of organizations, in so far as these consultations do not take place under a specific framework [7].

NGOs are not self-serving in aims and related values. Their aim is to act in the public arena at large, on concerns and issues related to the well being of people, specific groups of people or society as a whole. They are not pursuing the commercial or professional interests of their members. Though these common characteristics can help describe the notion of the term "NGO", it must be borne in mind that their size as well as their scope of activities can vary considerably. Some NGOs consist of a rather limited number of persons; others may have thousands of members and hundreds of professional staff. In functional terms NGOs can focus on operational and/or advocacy activities. Operational NGOs contribute to the delivery of services, whereas the primary aim of advocacy NGOs is to influence the policies of public authorities and public opinion in general [8].

\section{The role of NGO in the public crisis management}

With the development of public affairs management, it is urging to set up multi-cultural mechanism of crisis management. NGOs have been gradually the important part of the bodies of public affairs management and play important role in the public crisis management.

\subsection{Precautions of public crisis}

As for public crisis, it is better to prevent its emergence and eliminate the resources so as to cut down on a lot of social resources. Firstly, due to the voluntary, the NGOs maintain operation relying on people's voluntary participation. The members of NGOs have strong sense of mission to their undertaking and concern the induced factors of public crisis. Secondly, NGOs have the advantages of information. As a mechanism of social self-governance, NGOs are rooted in the society and close to the social situation, so they can understand the specific situations and response to public crisis positively. NGOs also can feedback the situations to the governments as soon as possibly and functions as an approach between people and government. The direct connection with people and society make NGOs observe the omen of public crisis firstly and put forward caution to society in time [9].

\subsection{Raiser and supervisor of public contingent resources}

Besides governments, NGOs are the major force to raise resources to reply the public 
crisis through the ways of appeal to the profit-making organizations or other organizations. In many public crises, a lot of public resources and voluntary resources are used [10].NGOs also can supervise the implementation of governmental decisions and relative decisions of international organizations. On the one hand, because the prevention of public crisis is a kind of complex system program, the government can not implement it by itself. However, NGOs can follow the tracks of public crisis and provide professional advisory information to governments. NGOs' participation and supervision will benefit the correct decisions of governments and guarantee the implementation of measures of public crisis prevention. On the other hand, the public crisis involves the allocation and use of a lot of public resources and voluntary resources, so the supervision of NGOs will make the public resources used legally and better [11].

\subsection{Actor of public crisis settlement}

The characteristics of NGOs make them become the important actor during the settlement of public crisis. Once the crisis happens, NGOs can launch and organize a lot of nongovernmental specialized persons and short-run supply. NGOs also can concern those people whose benefits can not be protected in time by governmental sectors. After the public crisis, NGOs can provide services for the regional reconstruction and restoration of social order and persuade those people who are influenced by crisis to set up confidence on the future live and work. In a word, the participation of NGOs will promote the people to function their initiative, form independent ability to organize, realize social self-management and benignant mutual promotion between NGOs an governments, and contain public crisis rapidly [12].

\subsection{Vindicator and protector of basic legal rights of social vulnerable group}

As an important force of crisis relief, NGOs also play the role of vindicator and protector of basic rights of social vulnerable group. Generally, due to the sudden of public crisis, it takes time for the governmental professionals to reach scene to implement rescue. Under the context, NGOs such as community organizations and voluntary organizations can implement rescue so as to control expand of incidents, prevent larger cost, guarantee effectively the basic interests of people. After the public crisis, NGOs have the abilities to raise a lot of medical resources which can be sent to disaster areas in time. Moreover, NGOs also can organize people through its advantages, help them set up confidence and obtain rights. So NGOs can be the spokesman of decentralized agents to settle all kinds of conflicts brought by crisis incidents relieve social contradiction in some extent and maintain social stability.

\section{The dilemma for the development of NGO in China}

\subsection{The serious lack of resources}

The lack of resources for NGOs is included the following two aspects, namely the lack of personnel and the lack of funds.

Firstly, NGOs can not attract professionals due to all kinds of reasons. The members' educational background of NGOs in China are generally low, namely most members' of NGOs hold the diploma of higher school, junior college and undergraduate. Most of members of NGOs are from governmental 
sectors or institutional organizations and many people responsible once worked in the governmental sectors. The average professional level is very low which has influenced the development of NGOs in China.

Secondly, as for funds, the lack of funds is very serious for most of NGOs. Due to the serious lack of funds, NGOs can not implement many activities, especially in face of huge natural disasters. [13]. From the present situation, it is very difficult for NGOs to raise funds even from governmental sectors. Thus a lot of NGOs have to obtain more funds through commercial activities.

\subsection{The legal system need to be improved}

The legal system for NGOs to participate in public crisis management refers to the rights through which NGOs can participate in public crisis management legally instead of being arranged by any governmental sectors. The legal system for NGOs to participate in public crisis management is establishing and improving in China, so there are not specific regulations about the rights and obligations for NGOs to participate in public crisis management at present. The lag of legal system for NGOs to participate in public crisis management results in a series of consequences. Especially, the participation of NGOs in public crisis management can not be paid attention and the ideals of NGOs can not be realized successfully [14].

\subsection{Immature civil society influence the development of NGO}

The western countries have deep-seated cultural deposits such as consciousness of citizenship and civic virtues. However, there is not the tradition of self-governance in China. Most people have no the sense or concept of self-governance. Due to the lag of regular decision system, the public governance structure with efficient mutual promotion have not formed, so the local government generally did not settle the problem about how to mobilize the social resources to construct and improve the network of dealing with public crisis. The public lack the awareness to responds to public crisis. People still mainly rely on governmental sectors to settle problems instead of NGOs or other autonomous organizations. Thus the NGOs can not be understood and identified in the public crisis management. On the other hand, during the transformation of society, the traditional social value system and ethics have been influenced hugely and the concept of public welfare has been gradually vague, which also influences the development of public rational knowledge, volunteerism, public-spirited and social credibility. These factors often result in the distrust of government and the public toward NGOs [15].

\subsection{Unbalanced development of NGOs}

The development of NGOs in China present huge gap in different regions. In the aspect of regions, NGOs in the developed coastal regions are better than those in western regions. Most of NGOs are centered in large or middle cities and have more influence on people or government. There are few NGOs in the rural regions, especially small-middle towns besides those NGOs which aim to eliminate poverty.

In the aspect of different fields, due to some political reasons, NGOs can not enter those fields which have a lot of social problems and need the participation of NGOs such as unemployment and employment, social security, labor rights protection, international regional conflicts and so on. Apparently, some 
legal or institutional factors have seriously influenced the development of NGOs in China.

\section{The ways to strength the role of NGO in the public crisis management}

\subsection{Optimizing the external environment} for NGOs and realizing the benignant mutual promotion among government, NGOs and the public

The benignant cooperation between government and NGOs is the way to realize effectively new model of public crisis governance. In the public crisis governance, NGOs should play effective role of relief through rescue in time, providing technologies and resources, so as to build up a bridge among government, the public and society and make up the defaults of governmental sectors.

The governmental sectors should transform the concepts and gradually establish new management system of separate supervision, resources guide and behavior control. The government should provide equal opportunities to participation, authorize NGOs to implement rescue work and regulate their rights and obligations of participation in public crisis management through setting up regulations. At the same time, the government should strengthen the guide and supervision on the NGOs so as to give full play to their positive role [13].

The benignant mutual promotion between NGOs and civil society is the base for their participation in public crisis management. During the public crisis, the resources such as personnel, goods and information are in short supply and the government can not independently control effectively large-scale crisis incident effectively in short time. Thus the social cooperative partnership and social cooperative network should be established rapidly under the guide of government. The public are the direct victims of public crisis incidents so the safety of people's life and property becomes the most important tasks. However, the public's awareness of crisis and ability to prevent crisis are the important factors that decides the quality of crisis management. Confront with crisis incidents, NGOs can laugh actively the public to implement self-countermeasures, fully integrate nongovernmental resources and expand the social base of crisis management. NGOs also can strengthen communication and cooperation with news media, give full play to the supervision by public opinion and strengthen the transparency of crisis management [14].

\subsection{Strengthening the financial support on NGO}

Many NGOs lack stable sources of funds, so the employees 'salary can not be guaranteed, even the daily operation. The volunteers have to spend their own money to pay the fee of travel and lodging. The lack of funds has serious restrict the role of NGOs and their sustainable development [15].

Generally, NGOs have the nature of independence and nongovernmental which requires that its source of fund should be service income instead of governmental financial appropriations. However, as for these NGOs which have undertake some public affairs management should be support from government. The model that government allocates some financial support to the NGOs is a general way in many developed countries. Moreover, the government can also provide some support for NGOs through preferential 
tax policies and project support so as to guarantee enough fun for NGOs to deal with the public crisis [16].

\subsection{Establishing platform and network of communication for information}

With the transformation of modern society, the system of unit is changing increasingly and the extent of personal movement is higher than ever, so those people who are not belong to any organization is more and more. How to organize or regulate those people has become a big social problem, especially for governments. As a link between government and the public, NGOs can pass on governmental policies and information to the public, explain the causes and damage of crisis to society by its professional advantages and put forward all kinds of advices in order to help improve the public's awareness of crisis, eliminate the sense of afraid and strengthen the public's confidence and social responsibility. On the other hand, NGOs can also pass on the public's benefits and needs to government, help government understand situations and problems so as to decrease the cost of collecting information, improve administrative efficiency and decrease social contradictions. Thus the social environment of replying to public crisis can be set up easily and all kinds of resources can be used in the public crisis management [17].

\subsection{Improving the public's enthusiasm on the NGO and public undertakings}

The participation into NGOs is another nature which is different from government and market. Almost all NGOs are relying on people's voluntary participation. Generally, the social culture which is autonomous will be more easy to promote the establishment and development of NGOs. In China, the cultivation of social spirit and formation of independent modern personality is essential for NGOs. The voluntary of NGOs means that people participate in NGOs is relying on people's sense of social responsibility and sense of mission. So it is necessary to cultivate people's social ethics and sense of mission besides independence and autonomy [18].

\section{Conclusions}

The settlement of public problems needs the cooperation and mutual promotion among government, society and citizens, which is a kind of ideal situation according to modern governance theory. From the characteristics of governmental organizations and their advantages and role, it is clear that NGOs have already been essential social resources during the settlement of public crisis management. The cooperation and mutual promotion between government and NGOs as well as full integration and use of social resources will effectively respond to public crisis. Thus during the process of building up harmonious society, it is necessary to develop and regulate NGOs, expand the channels and approaches for NGOs to participate in public crisis management and establish relative regulations [19].

In a word, NGOs in China are been the initiative phrase, so their advantages have not been given full play to, especially confronting with some significant natural disasters. The development of NGOs need more support from governments at all levels so as to promote NGOs' development healthily and make them become important force in the public crisis management [20]. 


\section{References}

[1][9] HUANG Wenbing. NGOs: the substantial force in the public crisis management[J]. Legal System and Society, 2008(6):155.

[2] Vakil, Anna C. confronting the classification problem: Toward taxonomy of NGOs[J]. World Development, 1997, 25(12): 2057-2070.

[3] P. Willetts. The Conscience of the World'. The Influence of Non-Governmental Organizations in the UN System[M]. Brookings Institution Press, 1996:27-29.

[4] Glasius, Marlies, Mary Kaldor and Helmut Anheier. Global Civil Society[M]. London: Sage, 2005:27-29.

[5] LSE.ac.uk, Mukasa, Sarah. Are expatriate staff necessary in international development NGOs? A case study of an international $\mathrm{NGO}$ in Uganda [R]. Publication of the Centre for Civil Society at London School of Economics. 2002: 11-13.

[6] Stone, Diane. Transfer Agents and Global Networks in the 'Transnationalisation' of Policy, Journal of European Public Policy, 2004, 11(3): 545-66.

[7] Subcontracting Peace. The Challenges of NGO Peacebuilding[M]. Edited by: Richmond, Oliver P., and Carey, Henry F. Published by Ashgate, 2005:21.

[8] Romano Prodi and Neil Kinnock. The Commission and Non-Governmental Organizations: Building a Stronger Partnership[R]. European Commission discussion paper, COM (2000) 11 of 18/01/2000.

[10][16] ZHANG Gaiqing. The role and status of NGOs in dealing with public crisis $[\mathrm{J}]$.
Journal of Shanxi Agric. Univ., 2007(6):155-157.

[11] TANG Jian. NGOs: the important force to deal with public crisis[J]. Administration and Law, 2006(12):42-44.

[12][19] DONG Haijun. NGOs and the public crisis management in China[J]. Journal of the Party School of Nanchang CPC Committee, 2008(2):43-45.

[13] [21] LI Hua, XU Yanhong. The difficult and countermeasures for NGOs' participation in the public crisis management[J]. ChongQing Administration, 2008(6):40-42.

[14][18] XU Zurong. The realistic situations for NGOs' participation in public crisis management[J]. Journal of Wuhan Uni. Of Sci. \& Tech., 2008(6):53-57.

[15][20] GE Xiaomei, HE Changjiang. The difficult and alternatives for NGOs' participation in public crisis management during the transformation period[J]. Guizhou Social Science, 2011(1):53-56.

[17][22] YANG Fang. The role of NGOs in the public crisis management[J]. Journal of Liaoning Administrators College of Police and Justice, 2007(4):46-48.

[23] SHI Kui. The role of NGOs in the crisis management[J]. Journal of Guilin University of Electronic Technology, 2004(1):73-76. 